\title{
A Comparative Analysis of Ripening and Fruit Quality as Affected by Artificial Ripening Agents: A Review
}

\author{
Laitonjam Avanti Devi and Anis Mirza* \\ Department of Horticulture, SAGR, Lovely Professional University, Punjab, India \\ *Corresponding author
}

\section{A B S T R A C T}

\begin{tabular}{|l|}
\hline Ke y w o r d s \\
Physiological, \\
Biochemical, \\
Climacteric, \\
Banana, Ripening \\
\hline Article Info \\
\hline $\begin{array}{l}\text { Accepted: } \\
\text { 15 October } 2020 \\
\text { Available Online: } \\
10 \text { November } 2020\end{array}$ \\
\hline
\end{tabular}

Ripening is the final stage in the life cycle of a fruit and it is an irreversible process. During ripening, fruits undergo various physiological and biochemical changes. These changes includes conversion of sugar from one form to another, textural changes, colour changes, change in aroma and flavor. Banana is one of the most easily available climacteric fruit which is distributed throughout the world. Since it is a climacteric fruit, its commercial ripening can be carried out in storage houses to obtain good flavor, proper texture and uniform peel colour. Ethylene glycol, ethrel and ethephon are some of the most widely used and easily available ripening agents in the market. Banana fruits were treated with different concentrations of each of the above mentioned ripening agents. Different parameters like flavour, colour and time taken for ripening were studied and the results indicated that the treated fruits were more uniformly ripened than the untreated fruits. The treated fruits took less time to ripen than the untreated fruits. This artificial method of ripening can be useful for small scale farmers and traders as it assures good quality and takes less time for ripening.

\section{Introduction}

Banana is one of the world's oldest fruit. Its botanical name Musa paradisiaca and its names "Adam's fig" and "Apple of Paradise" are suggestive of its antiquity. It is a climacteric fruit which is edible and belongs to the genus Musa. The fruit is botanically a berry. It is elongated and slightly curved with starch rich flesh which is very soft and sweet in taste and is covered in rind which may be red, yellow, green, brown or purple when ripened. The process of fruit ripening occurs naturally, marked by transition from hard to soft texture, increase in sweetness and change in colour due to various physiochemical activities (Bouzayen et al., 2010; Brady, 1987; Prasanna et al., 2007). Different metabolic pathways are triggered due to involvement of certain genes which leads to changes in colour, hardness, acidity, flavor and aroma (Tucker and Grierson 1987; Lizada, 1993; Prasanna et al., 2007; Kendrick, 2009; Bouzayen et al., 2010; Singal et al., 2011; El Hadi et al., 2013).

During respiration, complex compounds are broken down into smaller and simpler molecules and energy is released. The process of respiration indicates metabolic activity of 
cell and various phases of fruit development like ripening and senescence are reflected by respiratory patterns (Tripathi, Pandey, Malik, and Kaul, 2016). There is a close relationship between fruit and ethylene as it plays a key role in inception and senescence. Fruits are divided into two groups: climacteric and nonclimacteric fruits based on the mechanisms which govern the process of ripening. As ripening proceeds, there is a strong respiratory peak where there is high level of ethylene production in climacteric fruits while in nonclimacteric fruits, there is little or no increase in ethylene production along with constant respiration rate (Bouzayen et al., 2010).

Different compositional and structural changes during ripening, especially textural changes, make fruits appealing and fit for consumption. Depolymerization and solubilization of the components of cell wall and breaking of cell structure leads to textural changes (Li et al., 2010).

\section{Effect of ripening agents on fruit quality}

Ethylene $\left(\mathbf{C}_{2} \mathbf{H}_{4}\right)$ : Treatment of banana fruits can extend the shelf life without having a profound effect on peel colour, firmness and SSC content. Ethylene treatment can be provided by ethylene producing tablets which are available in different concentrations (Belew et al., 2016). Commercially, the concentration of ethylene gas used for ripening of banana ranges from $10-1000 \mu \mathrm{L} / \mathrm{L}$ (Saltveit, 1999). Ethylene gas shows no toxic effects in human but high cost is the main concern. The externally applied ethylene triggers the production of ethylene endogenously within the fruit (Liu et al., 1999). Ethylene prompts the development of colour, texture, aroma and flavor, reduce ripening variability and hence play a key role in ripening (Palomer et al., 2005; Lee et al, 2015). Ethylene treatment is given under controlled atmospheric conditions involving very specific regulation of temperature and relative humidity conditions (Lin et al, 2009).

Ethephon $\left(\mathrm{C}_{2} \mathrm{H}_{6} \mathrm{ClO}_{3} \mathrm{P}\right)$ : Ripening of fruits with ethephon is permissible if used in a limited concentration. It also takes less time and has longer shelf life as compared to those ripened with Calcium carbide. The fruits have more acceptance due to its better colour when compared to naturally ripened fruits (UrRahman et al, 2008). Ethephon at neutral $\mathrm{pH}$ reacts with moisture present in the atmosphere and produces ethylene gas, biphosphateion and chloride ions (Goonatilake, 2008). It also produces toxicity when used in high concentration indiscriminately causing salivation, defecation and urination (Dhembare, 2013). Bananas ripens with ethephon contains more nutritional quality when compared to Calcium carbide (Gunasekara et al., 2015). Different concentrations of ethephon can have remarkable effects on the physiological changes that occur during ripening and most ideal concentration for early ripening is 1000ppm (Pendharkar et al., 2011). Cavendish banana fruits treated with ethephon shows better sensory quality as compared to traditional smoke treatment (Anonymous, 2003).

Ethylene glycol $\left(\mathrm{C}_{2} \mathrm{H}_{6} \mathrm{O}_{2}\right)$ : Ethylene glycol contains impurities like diethylene glycol, triethylene glycol, etc. It can cause kidney failure in humans (Hanif et al., 1995; O'Brien et al., 1998). It is a liquid that is colourless, odourless and sweet in taste. It is very expensive but it can be diluted in water and used as a ripening agent (Anonymous, 2003). It can be used as a ripening agent in colder climatic environment especially in those countries having colder climatic conditions persisting throughout the year which delays the ripening of fruits in those areas (McCullough, 1979). Acidity of fruit plays a crucial role in ripening process. When the fruit is more acidic, the ripening process is faster. Bananas have an average acidity of 3.4 
$\mathrm{pH}$. The use of ethylene glycol as a ripening agent reduces to $75 \%$ as compared to the normal time period taken while ripening in colder conditions. Ethylene glycol is produced when ethylene gas reacts with hydrogen peroxide and it shows poisonous effects if ingested (Goonatilake, 2008). It can ripen different organic products quicker than the ordinary maturing rate of natural products. Water does not alter the ripening capacity of ethylene glycol.

Methyl jasmonate: It is an important agent required for seed germination, root growth, fertility, fruit ripening, etc. (Wasternack and Parthier, 1997). Due to its key role in ripening process, it is also used as an artificial ripening agent (Asif, 2012; Islam et al., 2018). Treatment with methyl jasmonate triggers the genes which are responsible for ripening process. It can also be used to induce ripening in non-climacteric fruits. Methyl jasmonate is a non-toxic substance however it is very expensive (Ur-Rahman et al., 2008).

Calcium carbide $\left(\mathrm{CaC}_{2}\right)$ : It is a very cheap substance hence it is widely used for ripening fruits like bananas and mangoes. Due to its harmful effects on human health, it is banned for commercial ripening process. It reacts with the moisture present in the atmosphere and produces acetylene gas which have properties similar to ethylene gas as long as ripening is concerned. Concentration of acetylene should be $2.8 \mathrm{ml} / \mathrm{L}$ because it has lower biological activity than ethylene (Burg and Burg, 1967). Ripening can be amplified by acetylene gas produced from Calcium carbide and treated fruits are more soft, uniformly coloured and contain medium starch as compared to the untreated ones (Hartshorn, 1931). It contains traces of highly toxic substances like arsenic and phosphorous which have carcinogenic properties (Ajayi and Mbah, 2007; Hakim et al., 2012; Siddiqui and Dhua, 2010). Direct contact with eye can cause permanent damage and it can also inflame the skin and cause burning sensation when it touches the skin. Accidental ingestion can cause coughing, wheezing and stomach disorder. It can also affect the nervous system badly by lowering the oxygen supply to the brain (Dhembare, 2013). Acetylene gas when inhaled accidentally can cause headache, dizziness, seizure and in most cases, it can induce comma (Fattah and Ali, 2010). The form of Calcium carbide available in the market has $80-85 \%$ purity and is of grey or brown colour (Gupta, 2017). Banana fruits treated with Calcium carbide have shorter shelf life as compared to those ripened naturally but the firmness is almost similar (Lin et al., 2009).

\section{Effects of treatment of artificial ripening agents on ripening and nutritional quality of banana}

Banana fruits treated with Calcium carbide are found to contain higher levels of $\mathrm{Pb}, \mathrm{Cu}$, $\mathrm{Zn}$ and $\mathrm{Mn}$ as compared to fruits which are ripened naturally (Lustre et al., 1976).Aromic concentration and sucrose level is comparatively higher in bananas that are naturally ripened than ethylene treated bananas (Sonmezdag et al., 2014). At full yellow stage, naturally ripened banana fruits possess better sensory quality, flavor, taste as compared to Calcium carbide treated fruits (Sarananda, 1990). Protein content is found to be more in naturally ripened bananas as compared to artificially ripened ones where chemical ripening agents are used (SogoTemi et al., 2014).

In conclusion, it is evident that commercial ripening using artificial ripening agents have become a very important aspect in the fruit industry. The present study indicates that the use of ripening agents enhances the ripening process and saves time. However, some of these chemical agents like Calcium carbide 
produces acetylene gas when it reacts with water and it is hazardous to health. Also, minimal concentration of ethephon is permissible but high concentration can lead to serious health consequences. Ethylene glycol is preferred in colder climatic environment but it can also show potential health risks like kidney failure if ingested. It is always a wise option to use the natural ripening agent which is ethylene, the only natural plant hormone and ripening agent.

\section{References}

Ajayi, A.R. and Mbah, G.O. (1997). Identification of indigenous ripening technologies of banana and plantain fruits among women- marketers in Southeastern Nigeria. Journal of Agriculture, Food, environment and Extension, 6(2): 60-66.

Belew, D., Park, D.S., Tilahun, S. and Jeong, C.S. (2016). The effects of treatment with ethylene-producing tablets on the quality and storability of banana (Musa sp.). Korean Journal of Horticultural Science and Technology, 34(5): 746-754

Bouzayen, M., Latche, A., Nath, P., and Pech, J. C. (2010). Mechanism of fruit ripening. In E. C. Pua and M. R. Davey (Eds.), Plant developmental biology Biotechnological perspectives. New York, NY: Springer-verlag berlin Heidelberg.

Bouzayen, M., Latché, A., Nath, P. and Pech J.C. (2010). Mechanism of fruit ripening, in Plant Developmental Biology-Biotechnological Perspectives, Springer, Berlin, Germany, Pp. 319339.

Burg, S.P. and Burg, E.A. (1967). Molecular requirements for the biological activity of ethylene. Plant Physiology, 42(1): 144-152

Dhembare, A.J. (2013). Bitter truth about fruit with reference to artificial ripener.
Achieves of Applied Science Research, 5(5): 46- 48.

Goonatilake R. (2008). Effects of diluted ethylene glycol as a fruit- ripening agent. Global Journal of Biotechnology and Biochemistry, 3(1): 8-13.

Gunasekara, S.R.W, Hemamali, K.K.G.U., Dayananada, T.G. and Jayamanne, V.S. (2015) Postharvest quality analysis of 'embul' banana following artificial ripening techniques. International Journal of Science, Environment and Technology. 4(6): 1625-1632.

Gupta, R. (2017). Artificial ripening of fruits and effects on health. In: proceedings of 6th International Conference on Recent Trend in Engineering, Science and Management (ICRTESM-17), Punjab, India.: 341-345.

Fattah, S. and Ali, M. (2010). Carbide ripened fruits- a recent health hazard. Faridpur Medical College Journal, 5(2): 37

Hakim, M.A., ObidulHuq, A.K., Alam, M.A., Khatib, A, Saha, B.K., FormuzulHaque, K.M., and Zaidul, I.S.M. (2012). Role of health hazardous ethephone in nutritive values of selected pineapple, banana and tomato. Journal of Food, Agriculture and Environment. 10(2): 247-251.

Hanif, M, Mobarak, M.R., Ronan., A., Rahman., D., Donovan Jr., J.J., Bennish, M.L. (1995). Fatal renal failure caused by diethylene glycol in paracetamol elixir: The Bangladesh epidemic. British Medical Journal, 11: 88-91.

Hartshorn, R. (2016). Some efects of acetylene on the ripening processes of bananas, Plant Physiology, 6(3): 467

Islam, M.N., Imtiaz, M.Y. and Alam S.S. (2018). Artificial ripening on banana (Musa spp.) samples: analyzing ripening agents and change in nutritional parameter, Cogent Food \& Agriculture.

K. H. Sarananda, Effect of calcium carbide on ripening of Embul banana (Musa spp.). 
Tropical Agriculturist (Sri Lanka), 1990.

Kulkarni, S.G., Kudachikar, V.B. and Keshava Prakash. M.N. (2010). Studies on physico-chemical changes during artificial ripening of banana (Musa sp) variety 'Robusta'. Journal of Food Science and Technology, 48(6):730-734.

Lee I, Im S, Jin CR, Heo HJ, Cho YS, Baik MY, Kim DO. (2015). Effect of maturity stage at harvest on antioxidant capacity and total phenolics in kiwifruits (Actinidia spp.) grown in Korea. Horticulture, Environment and Biotechnology, 56: 841-848.

Lin, Z., Zhong, S. and Grierson, D. (2009). Recent advances in ethylene research. Journal of Experimental Botany, 60(12): 3311-3336.

Li, X., Xu, C., Korban, S.S. and Chen, K. (2010). Regulatory mechanisms of textural changes in ripening fruits. Critical Reviews in Plant Science, 29(4): 222-243.

Liu, X., Shiomi, S., Nakatsuka, A., Kubo, Y., Nakamura, R. and Inaba, A. (1999). Characterization of ethylene biosynthesis associated with ripening in banana fruit. Plant Physiology, 121: 1257-1265.

doi:

http://dx.doi.org/10.1104/pp.121.4.1257

Lustre, O., Soriano, M.S., Morga, N.S., Balagot, A.H. and Tunac, M.M. (1976). Physico-chemical changes in 'Saba' bananas during normal and acetyleneinduced ripening. Food Chemistry, 1(2): 125-137.

McCullough, A. (1979). Fruit -Ripening and chemical reaction. Chemical reactions in nature, Vanderbilt University Press.

O’Brien, K.L., Selanikio, J.D., Hecdivert, C., Placide, M.F., Louis, M., Barr, D.B. and Philen, R.M. (1998). Epidemic of pediatric deaths from acute renal failure caused by diethylene glycol poisoning. 279 (15): 1175-1180.
Palomer, X., Roing-Villanova, I., GrimaCalvo, D. and Vendrell, M. (2005). Effects of nitrous oxide $\left(\mathrm{N}_{2} \mathrm{O}\right)$ treatment on the postharvest ripening of banana fruit. Postharvest Biology and Technology, 36: 167-175. doi: http://dx.doi.org/10.1016/j.postharvbio. 2004.12.008

Pendharkar, P.Y., Hiwale, S.S., and Patilstudies, H.B. (2011). Studies on the effect of post harvest treatments on chemical changes during ripening of banana fruits cv. grand naine. International Journal of Processing and Post Harvest Technology, 2(1): 32-34

Tripathi, K., Pandey, S., Malik, M. and Kaul, T. (2016). Fruit ripening of climacteric and nonclimateric fruit. Journal of Environmental and Applied Bioresearch, 4: 27-34

Saltveit, M.E. (1999). Effect of ethylene on quality of fresh fruits and vegetables. Postharvest Biology and Technology 15: 279-292. doi: http://dx.doi.org/10.1016/S09255214(98)00091-X

Siddiqui MW, Dhua RS. Eating artificial ripened fruits is harmful. Current Science. 2010; 99(12): 1664-8.

Sogo-Temi, C.M., Idown, O.A. and Idowu. E. (2014). Effect of biological and chemical ripening agents on the nutritional and metal composition of banana (Musa spp). Journal of Applied Sciences and Environmental Management, 18(2): 243- 246.

Sonmezdag,S., Kelebek, H. and Selli, S.(2014). Comparison of the aroma and some physicochemical properties of grand naine (Musa acuminata) banana as influenced by natural and ethylenetreated ripening. Journal of Food Processing and Preservation, 38(5): 2137-2145

Tucker, G.A., and Grierson, D. (1987). Fruit ripening. In D. D. Davies (Eds), The 
biochemistry of plants (pp. 265-319). New York: Academic Press. [Google Scholar]

Wikipedia Encyclopedia, 2003. Ethylene, Ethylene Glycol, Retrieved September, 14, 2006 from www.wikipedia.com/ ethylene

Ur-Rahman, A., Chowdhury, F.R. and Alam, M.B. (2008) Artificial ripening: what we are eating. Journal of Medicine,9(1): 42-4.

Zenebe, W.A., Ali, M.I., Derbew, B.Y. and Tarekegn, A.W. (2015). Effect of traditional kerosene smoking and ethrel on ripening, shelf life and quality of Cavendish banana (Musa sp.). African Journal of Agricultural Research, 10(50): 4570-4583.

\section{How to cite this article:}

Laitonjam Avanti Devi and Anis Mirza. 2020. A Comparative Analysis of Ripening and Fruit Quality as Affected by Artificial Ripening Agents: A Review. Int.J.Curr.Microbiol.App.Sci. 9(11): 1786-1791. doi: https://doi.org/10.20546/ijcmas.2020.911.211 